\title{
Argan (Argania spinosa (L.) Skeels) seed germination under nursery conditions: Effect of cold storage, gibberellic acid and mother-tree genotype
}

\author{
Mohamed AlOUANI, Fouzia BANI-AAMEUR* \\ Laboratoire de Recherche sur la Variabilité Génétique, Université Ibn Zohr, \\ Faculté des sciences, Département de Biologie, BP 28/S- 80000 Agadir, Morocco
}

(Received 6 February 2002; accepted 3 January 2003)

\begin{abstract}
The aim of this study is to assess argan (Argania spinosa) seed germination of ten argan mother-trees after four different cold storage durations with or without gibberellic acid (GA) treatment for the purpose of establishing a simple germination procedure adaptable to various nursery situations. The beginning of germination of argan seeds which, were stored at room temperature in the absence of GA treatment, was delayed for 3.4 days in average in comparison with chilled and GA-treated seeds. Germination was as low as 35.5\% and seed deterioration as well as pre-emergence seedling dumping-off was important. In contrast, either GA application or cold storage at $4{ }^{\circ} \mathrm{C}$ for at least one month significantly led to a two-fold increase of germination attaining approximately $60 \%$ and a better control of dormancy. Indeed, average germination was even higher when both treatments were combined (79.5\%), mostly because GA combined to cold storage of the seeds for longer than one month periods decreased losses due to seed fungi contamination or to pre-emergence seedling dumping-off. Final germination percentage was enhanced by cold storage for the longest periods (three months) attaining values higher than $95.0 \%$ depending on mother tree genotype.
\end{abstract}

Argania spinosa / reforestation / dormancy / germination / gibberellic acid

Résumé - Germination des semences d'arganier (Argania spinosa (L.) Skeels) en pépinière : effet du froid, de l'acide gibbérellique et du génotype du pied-mère. Cette étude porte sur les effets de quatre durées de conservation des semences au froid, avec ou sans traitement à l'acide gibbérellique (GA), sur la germination des noyaux de dix pied-mères d'arganier (Argania spinosa) en vue d'établir un protocole simple de germination adaptable à des situations diverses. Le début de la germination des semences d'arganier non traitées par GA et conservées à la température ambiante est retardé de trois jours par comparaison avec les semences stockées au froid ou traitées par GA. La germination est faible $(35,5 \%)$ et la contamination des semences ainsi que la fonte de semis en pré-émergence sont importantes. Par contraste, l'application de GA ou le stockage au froid à $4{ }^{\circ} \mathrm{C}$ pendant un minimum de un mois permet une augmentation significative de la germination qui atteint $60 \%$. La germination moyenne augmente remarquablement quand les deux traitements sont combinés (79,5\%), ceci étant surtout du au fait que l'application de GA après stockage au froid réduit les pertes dues à la contamination par les champignons et à la fonte de semis en préémergence. Dans ces conditions, et quand les semences ont été stockées au froid pendant trois mois, le pourcentage final de germination a pu atteindre $95,0 \%$ en fonction du pied-mère.

Argania spinosa / reboisement / dormance / germination / acide gibbérellique

\section{INTRODUCTION}

Argan tree (Argania spinosa (L.) Skeels) is endemic to south west of Morocco, an arid Mediterranean type area where rainfall occurs in the winter $[9,14]$. Although it is a recognised oil, forage and timber tree highly adapted to aridity, it is threatened by large-scale destruction, over-use and the lack of natural regeneration $[8,16]$. Past assays of artificial reforestation using nursery grown seedlings were not successful either [13].
Germination and early seedling development stages are critical periods for the establishment of plant species [12]. Indeed, basic and practical argan nursery seedling production for reforestation is still at its beginning. Nursery seedling production was heterogeneous and seedling emergence did not exceed $18 \%$ [1]. It was demonstrated that argan germination requires night temperature higher than $10^{\circ} \mathrm{C}$ [21]. But, even under these conditions, it has been shown that viability and seed dormancy were limiting factors. One-month cold storage, stone scarification

\footnotetext{
* Corresponding author: baniaameur@hotmail.com
} 
Table I. Analyses of variance of emerged seedling number (ES), time to germination (TG), germination period (GP), pre-emergence dumpedoff seedling number (GC), number of deteriorated seeds (RS) and dormant seeds (DS) for ten argan mother-trees at four cold storage durations and two gibberellic acid treatments.

\begin{tabular}{|c|c|c|c|c|c|c|c|}
\hline \multirow{2}{*}{ Source of variation } & \multirow{2}{*}{ DF } & \multicolumn{6}{|c|}{ Mean squares } \\
\hline & & ES & TG & GP & GC & $\mathrm{RS}$ & DS \\
\hline Block & 1 & $1.23 \mathrm{~ns}$ & $4.90 \mathrm{~ns}$ & $90.00 *$ & $0.23 \mathrm{~ns}$ & $2.26 \mathrm{~ns}$ & $0.03 \mathrm{~ns}$ \\
\hline Mother-tree & 9 & $7.37 * *$ & $14.07 \mathrm{~ns}$ & $28.84 \mathrm{~ns}$ & $1.04 \mathrm{~ns}$ & $3.85 * *$ & $0.14 \mathrm{~ns}$ \\
\hline Cold storage (CS) & 3 & $40.76 \mathrm{~ns}$ & $23.94 *$ & $160.24 * *$ & $3.03 * *$ & $2.22 \mathrm{~ns}$ & $14.04 \mathrm{~ns}$ \\
\hline Gibberellic acid (GA) & 1 & $75.63 *$ & $448.90 * *$ & $442.22 * *$ & $0.40 \mathrm{~ns}$ & $18.90 * *$ & $22.5 \mathrm{~ns}$ \\
\hline Mother-tree x CS & 27 & $0.68 \mathrm{~ns}$ & $6.18 \mathrm{~ns}$ & $15.45 \mathrm{~ns}$ & $0.59 \mathrm{~ns}$ & $0.53 \mathrm{~ns}$ & $0.13 \mathrm{~ns}$ \\
\hline Mother-tree $\times$ GA & 9 & $0.78 \mathrm{~ns}$ & $4.01 \mathrm{~ns}$ & $11.84 \mathrm{~ns}$ & $0.30 \mathrm{~ns}$ & $0.92 \mathrm{~ns}$ & $0.33 \mathrm{~ns}$ \\
\hline $\mathrm{CS} \times \mathrm{GA}$ & 3 & $6.49 * *$ & $5.75 \mathrm{~ns}$ & $6.18 \mathrm{~ns}$ & $1.27 \mathrm{~ns}$ & $2.60 \mathrm{~ns}$ & $10.88 * *$ \\
\hline Mother-tree $\times \mathrm{CS} \times \mathrm{GA}$ & 27 & $1.03 \mathrm{~ns}$ & $9.36 \mathrm{~ns}$ & $22.23 *$ & $0.65 \mathrm{~ns}$ & $0.45 \mathrm{~ns}$ & $2.16 \mathrm{~ns}$ \\
\hline Error & 79 & 1.21 & 7.58 & 13.39 & 0.6 & 0.69 & 0.26 \\
\hline
\end{tabular}

DF: degrees of freedom; ** significant at $0.01 ; *$ significant at 0.05 ; ns: non significant.

plus fungicide application and gibberellic acid (GA) treatment alleviate dormancy and increase germination rates up to $90 \%$ depending on mother-tree genotype [3].

Argan area in the south west of Morocco is a UNESCO MAB (Man And the Biosphere) Reserve where national and international Non Governmental Organizations are actually at work, aiming to contribute to rural communities well being and environment preservation, mostly because of encroaching desert threat. Thereafter, argan regeneration, an overwhelming task, becomes a priority for organizations disposing of relatively well equipped nurseries as well as for grouped villagers with reduced nursery facilities, especially the lack of electricity and refrigeration equipment. The objective of the present study is to establish a simple procedure for argan seed germination that is adaptable to various nursery situations. Our specific objective is to assess argan seed germination of ten argan mothertrees after four different cold storage durations with or without GA treatment.

\section{MATERIALS AND METHODS}

Argan fruit is a drupe containing a stone of one to five nuts [4]. Ripe argan fruits were collected during August 1998 from ten argan trees growing in Ait Baha (south-west Morocco). Four lots of forty ripe and dry fruits from each mother-tree were collected in September 1997 and stored in polyvinyl bags at room temperature then at cold storage $\left(4{ }^{\circ} \mathrm{C}\right)$ following four scenarios: no cold storage (control), cold storage during the last month of storage, or during two months or three months. On May 1998, the protocol for pre-treatment of argan stones set forth by Bani-Aameur and Alouani [3] was followed. The fruits were hulled and the stones were scarified by slightly cracking them and then immediately soaked in $2 \%$ chlorine solution for $15 \mathrm{~min}$ followed by three fresh water rinses and dried at room temperature. They were then coated with the fungicide Thirame. A half of each seed lot (20 stones) were soaked for $24 \mathrm{~h}$ in a GA solution at $1000 \mathrm{PPM}$, whereas the second half was soaked in distilled water. Both lots were rinsed twice with fresh water before seeding.

A randomised complete block factorial design was used, with 10 mother-trees, four cold storage scenarios and two GA treatments as factors [21]. There were two blocks and the experimental unit was ten pre-treated seeds in $20 \mathrm{~cm} \times 15 \mathrm{~cm}$ plastic pots on a 1:1:1 mixture of peat moss, sand and argan forest soil. The seeds were planted one to two centimetres below the surface on May 25th 1998 when minimum temperature was higher than $10{ }^{\circ} \mathrm{C}$ and maximum temperature was not higher than $25^{\circ} \mathrm{C}$, which is favourable to argan seed germination [21]. They were irrigated every day with tap water to field capacity as necessary. Number of emerging seedling was recorded daily for 45 days when it levelled off. At the end of the experiment, germination was recorded according to the following categories according to Berrie [6]: (i) emerged seedling number (ES), (ii) time to germination as the time for the first germination to appear (TG), (iii) germination period as the time between the first germination and the end of germination (GP), (iv) dormant seeds i.e. seeds that did not deteriorate but did not germinate (DS), (v) pre-emergence dumped-off seedling number i.e. the number of contaminated non emerging sprouts (GC) and (vi) contaminated i.e. deteriorated seeds (RS).

Data were subjected to a four-way analysis of variance where mother-tree, cold storage, GA treatment and replication are crossed factors. As there is no mother tree interaction either with cold storage or with GA treatment, mother trees were further combined in a single 100 seeds $(10 \times 10$ seeds $)$ to explore treatments effects in a three way analysis of variance where cold storage, GA treatment and replication are crossed factors [17]. The LSD test $(\alpha=5 \%)$ of equality of means was used to compare significant factors means [20]. Statistix software was used for computation.

\section{RESULTS}

\subsection{Cold storage and GA treatment effect}

When data included mother tree effect (Tab. I) or when data were pooled over the three mother trees (Anova not shown), GA main effect was significant for germination, germination time, germination period and for contaminated seeds. Cold treatment duration was a highly significant main effect for germination time, germination period and for pre-emergence dumping off. The interaction GA cold was highly significant for germination and dormant seed number.

Mean germination of the control was low (35.5\%) (Tab. II). GA treatment increased average germination, decreased germination 
Table II. Mean emerged seedling number (ES), time to germination expressed in days (TG), germination period expressed in days (GP), preemergence dumped-off seedling number (GC) and number deteriorated seeds (RS) and dormant seeds (DS) for four cold storage duration and two gibberellic acid treatments (GA). Values are means of two replications of 100 seeds pooled over ten mother-trees.

\begin{tabular}{|c|c|c|c|c|c|c|}
\hline & \multirow[b]{2}{*}{ GA } & \multicolumn{4}{|c|}{ Cold storage duration (months) } & \multirow[b]{2}{*}{ Mean } \\
\hline & & 0 & 1 & 2 & 3 & \\
\hline \multirow{3}{*}{ ES } & No & $35.5 \mathrm{~b}$ & $58.5 \mathrm{a}$ & $61.0 \mathrm{a}$ & $62.0 \mathrm{a}$ & $54.3 \mathrm{~b}$ \\
\hline & Yes & $58.0 \mathrm{c}$ & $67.0 \mathrm{~b}$ & $67.5 \mathrm{~b}$ & $79.5 \mathrm{a}$ & $68.0 \mathrm{a}$ \\
\hline & Mean & 46.8 & 62.8 & 64.8 & 70.3 & 62.2 \\
\hline \multirow{3}{*}{ TG } & No & 16.9 & 15.7 & 14.9 & 14.5 & $15.5 \mathrm{a}$ \\
\hline & Yes & 12.6 & 12.5 & 12.3 & 11.3 & $12.1 \mathrm{~b}$ \\
\hline & Mean & $14.8 \mathrm{a}$ & $14.0 \mathrm{ab}$ & $13.7 \mathrm{ab}$ & $12.9 \mathrm{~b}$ & 13.8 \\
\hline \multirow{3}{*}{ GP } & No & 10.6 & 13.2 & 14.0 & 16.1 & $13.4 \mathrm{~b}$ \\
\hline & Yes & 14.2 & 17.0 & 17.7 & 18.2 & $16.8 \mathrm{a}$ \\
\hline & Mean & $12.4 \mathrm{c}$ & $15.1 \mathrm{~b}$ & $15.8 \mathrm{ab}$ & $17.1 \mathrm{a}$ & 15.1 \\
\hline \multirow{3}{*}{ GC } & No & 7.5 & 10.5 & 5.5 & 5.0 & 7.2 \\
\hline & Yes & $12.5 \mathrm{a}$ & $8.5 \mathrm{a}$ & $8.5 \mathrm{a}$ & $3.0 \mathrm{~b}$ & 8.2 \\
\hline & Mean & $10.0 \mathrm{a}$ & $9.5 \mathrm{a}$ & $7.0 \mathrm{ab}$ & $4.0 \mathrm{~b}$ & 7.7 \\
\hline \multirow{3}{*}{$\mathrm{RS}$} & No & 31.5 & 27.0 & 31.0 & 31.0 & $30.1 \mathrm{a}$ \\
\hline & Yes & $27.5 \mathrm{a}$ & $24.5 \mathrm{a}$ & $24.0 \mathrm{a}$ & $17.0 \mathrm{~b}$ & $23.3 \mathrm{~b}$ \\
\hline & Mean & 29.5 & 25.8 & 27.5 & 24.0 & 26.7 \\
\hline \multirow{3}{*}{ DS } & No & $25.0 \mathrm{a}$ & $4.0 \mathrm{~b}$ & $1.5 \mathrm{~b}$ & $3.0 \mathrm{~b}$ & $8.4 \mathrm{a}$ \\
\hline & Yes & 2.0 & 0.0 & 1.0 & 0.5 & $0.9 \mathrm{~b}$ \\
\hline & Mean & 13.5 & 2.0 & 1.3 & 1.8 & 4.7 \\
\hline
\end{tabular}

Different letters note significant differences (LSD at 0.05 level) as comparisons are made between cold duration means (horizontally for the four corresponding columns) or GA treatments means (vertically for the last column).

time of 3.4 days thus increasing germination period, reduced seed deterioration and decreased dormant seeds number (DS) from 8.4 to 0.9 . On the other hand, cold storage for long periods decreased average time to germination (TG) thus increasing germination period (GP), and decreased deteriorated seeds number (RS). As it is, applying either GA treatment or cold storage for one to three months helped to double germination attaining approximately $60 \%$ and to break dormancy in large proportions. When both treatments were combined, average germination attained $79.5 \%$, mostly because GA application combined to cold storage of the seeds for long periods decreased losses to seed fungi-contamination or to pre-emergence seedling dumping-off.

\subsection{Mother-tree genotype effect}

Mother-tree genotype main effect was highly significant for germination and seed deterioration but none of its interaction was significant (Tab. I). Therefore, cold storage and GA treatment are indifferent to genotype.

\section{DISCUSSION AND CONCLUSION}

\subsection{Cold storage and gibberellic acid treatment effect}

Exogenous GA has been applied to many species to cover embryo needs for stimulating germination, to increase embryo growth potential or to reduce seed cold requirements [7, 10, 11]. In the present study, applying either GA or cold storage increased germination, decreased time to germination extending germination period and reduced the number of dormant seeds i.e. seeds that did not deteriorate but did not germinate either, as it was shown for many species [7]. When cold storage was applied alone, germination (as well as number of dormant seeds) did not differ between cold storage periods, one month being enough to break dormancy. Indeed, the present study showed that combining both of GA and cold storage for longer periods increased germination rather because seed deterioration and pre-emergence dumping off were reduced (Tab. II). Still more research is needed for a better characterisation a possible synergetic effect of GA and cold in the case of argan seed germination. From the results of this study, dormancy can be broken using GA or cold storage, but the presence of GA appears to speed up germination avoiding long exposure of the seeds to contamination. This probably has to do with the fragility of the argan nut contained within the slightly cracked stone and weighing less $5 \mathrm{~g}$ in average [15] but rich in lipids and carbohydrates [15]. Therefore, in the absence of cold, the seeds treated with GA may wait longer in the pot before germination. They are then exposed for longer periods to fungi development and/or fatty acid oxidation into toxic components, proven to be deleterious to seed germination for many species $[18,19]$. As it is, to optimise argan seed germination when adequate nursery equipment is available, it would be advisable to 
use both GA treatment and cold storage for at least threes months. Indeed, when refrigeration facilities are lacking, soaking seeds in 1000 PPM GA solution for $24 \mathrm{~h}$ can still produce acceptable quantities of seedlings for artificial regeneration.

\subsection{Effect of mother-tree genotype}

GA treatment and/or seed cold storage positive effects on argan seed germination and dormancy breaking are independent from mother-tree genotype. However, genotype has a direct effect on germination (Tab. I), which according to previous studies might be due to differential sensibilities to fungi contamination [20]. Genotype has also an indirect effect on germination because argan senescent fruits are collected beneath tree canopy including a variable proportion of immature physiological losses which, depend on the genotype $[2,5]$. Moreover, because of differential trees precocity, ripe fruits may be more or less exposed to contamination and to unfavourable conditions to viability and germination $[18,19]$. At this stage, assorting ripe fruits from physiological losses and adapting harvest dates to individual mother-tree precocity may improve germination productivity.

Acknowledgements: We thank the Morocco-Germany co-operative project "Projet de Conservation et de Développement de l'Arganeraie"' (PCDA-GTZ) and the project Pars Agro 128 of the Morocan ministery of scientific research for financial support.

\section{REFERENCES}

[1] Alouani M., Bani-Aameur F., Limitations actuelles de la production et de la transplantation des plants d'arganier, in: Bani-Aameur F. (Ed.), Colloque International sur les Ressources Végétales : L'arganier et les plantes des zones arides et semi-arides, Faculté des Sciences d'Agadir 23, 24 et 25 avril 1998, 1999, pp. 180-184.

[2] Alouani M., Bani-Aameur F., Germination des semences d'arganier : effet des conditions de récolte, in: $4^{\mathrm{e}}$ Colloque International sur l'Arbre, Jardin Botanique de Montréal, 20-26 août 2000, p. 25.

[3] Bani-Aameur F., Alouani M., Viabilité et dormance des semences d'arganier, Ecol. Medit. 25 (1999) 75-86.

[4] Bani-Aameur F., Ferradous A., Dupuis P., Typology of Argania spinosa (Sapotaceae) fruits and stones, For. Genet. 6 (1999) 213-219.
[5] Bani-Aameur F., Louali L., Dupuis P., Maturation et chute des fruits de l'arganier, Actes de l'Institut Agronomique et Vétérinaire Hassan II 18 (1998) 136-144.

[6 ] Berrie A.M.M., Germination and dormancy, in: Wilkins M.B. (Ed.), Advanced Plant Physiology, Pitman Ltd. Melbourne, 1985, pp. 440468

[7] Bradbeer J.W., Seed dormancy and germination, Ed. Blackie, London, 1988.

[8] El Yousfi S.M., Benchekroun F., La dégradation forestière dans le sud marocain, exemple de l'arganeraie d'Admine (Souss) entre 1969 et 1986, Ann. Rech. For. Maroc 26 (1992) 43-49.

[9] Emberger L., Aperçu général sur la végétation du Maroc, Bull. Soc. Sci. Nat. Maroc, 1939, pp. 40-157.

[10] Evans A.S, Mitchell R. J., Cabin R.J., Morphological side effects of using gibberellic acid to induce germination: consequences for the study of seed dormancy, Am. J. Bot. 83 (1996) 543-549.

[11] Geneve R.L., Seed dormancy in eastern redbud (Cercis canadensis), J. Am. Soc. Hortic. Sci. 116 (1991) 85-88.

[12] Grime J.P., Campbell B.D., Growth rate, habitat productivity, and plant strategy as predictors of stress response, in: Mooney H.A., Winner W.E., Pell E.J., Chu E. (Eds.), Response of plants to multiple stresses, Academic Press, Inc., 1991, pp. 143-159.

[13] Hartmann H.T., Kester D.E., Davies F.T., Plant propagation principles and practices, Prentice Hall International, Inc., Singapore, 1990.

[14] Kitchen S.G., Meyer S.E., Seed germination of intermountain penstemons as influenced par stratification and GA3 treatments, J. Environ. Hortic. 9 (1991) 51-56.

[15] Maurin R., L'huile d'argan Argania spinosa (L.) Skeels Sapotaceae, Rev. Fr. Corps Gras 56 (1992) 139-146.

[16] Mellado M., SOS Souss: argan forest destruction in Morocco, Oryx 23 (1989) 87-93.

[17] Montgomery D.C., Design and Analysis of Experiments, 2nd ed., John Wiley \& Sons, New York, Chichester, Brisbane, Toronto, Singapore, 1984.

[18] Mycock D.J., Berjak P., The implication of seed associated flora during storage, in: Kigel J., Galili G. (Eds.), Seed development and germination, Marcel Dekker Inc., New York, Basil, Hong Kong, 1995, pp. 747-766.

[19] Smith M.T., Berjak P., Deteriorative changes associated with loss of viability of stored desiccation-tolerant and desiccation sensitive Leeds, in: Kigel J., Galili G. (Eds.), Seed development and germination, Marcel Dekker Inc., New York, Basil, Hong Kong, 1995, pp. 701-746.

[20] Sokal R.R., Rohlf F.J., Biometry, the Principles and Practice of Statistics in Biological Research, 3rd ed., WH Freeman and Company, New York, 1995

[21] Zahidi A., Bani-Aameur F., Germination des amandes d'arganier (Argania spinosa (L.) Skeels) : effet du génotype, de la date de semis et de l'année de récolte, Ann. Rech. For. Maroc 30 (1997) 2-16. 